\title{
Application of Artificial Neural Network to Predict the Effect of Paraffin Addition on Water Absorption and Thickness Swelling of MDF
}

\section{Primjena umjetne neuronske mreže za predviđanje utjecaja dodatka parafina na upojnost vode i debljinsko bubrenje MDF-a}

\author{
Original scientific paper • Izvorni znanstveni rad \\ Received-prispjelo: 30. 8. 2018. \\ Accepted-prihvaćeno: 4. 7. 2019. \\ UDK: $630 * 812.22 ; 630 * 812.23 ; 630 * 863.312$ \\ https://doi.org/10.5552/drvind.2019.1839
}

\begin{abstract}
In this study, water absorption and thickness swelling values of medium density fiberboard (MDF) were modelled by artificial neural networks (ANN). MDF panels were produced with different rates of paraffin (0.0-control, 0.5, 1 and $1.5 \%$ ) at different press temperatures $\left(170\right.$ and $\left.190{ }^{\circ} \mathrm{C}\right)$. After conditioning of MDF, water absorption (WA) and thickness swelling (TS) of samples were carried out at specific intervals within 24 hours. Then, the data obtained from these experiment were modelled using ANN. Paraffin addition rate, press temperature and immersion time in water were used as the input parameters, while WA and TS values of MDF were used as the output parameters. After training of ANN, it was found that correlation coefficients (R) were close to 1 for training, validation, test and all data set. Mean absolute percentage error (MAPE) and mean square error (MSE) were determined as $2.94 \%$ and 0.57 , respectively, for all data sets. As a result of this study, the use of proposed ANN model may be recommended to predict the water absorption and thickness swelling of panels instead of complex and time-consuming studies such as empirical formulas.
\end{abstract}

Keywords: artificial neural network, water absorption, thickness swelling, medium density fiberboard, paraffin

SAŽETAK • U istraživanju je modelirana upojnost vode i debljinsko bubrenje ploče vlaknatice srednje gustoće (MDF ploče) uz pomoć umjetnih neuronskih mreža (ANN-a). MDF ploče proizvedene su uz dodatak različitih količina parafina (0,0 - kontrola, 0,5; 1 i 1,5\%) pri različitim temperaturama prešanja $\left(170\right.$ i $\left.190{ }^{\circ} \mathrm{C}\right)$. Nakon kondicioniranja MDF ploče, mjerena je upojnost vode (WA) i debljinsko bubrenje (TS) uzoraka u određenim intervalima unutar 24 sata. Zatim su ti podatci modelirani uz pomoć ANN-a. Kao ulazni parametri poslužili su količina parafina, temperatura prešanja i trajanje namakanja uzoraka u vodi, dok su WA i TS vrijednosti MDF ploče korištene kao izlazni parametri. Nakon provedbe ANN-a utvrđeno je da su koeficijenti korelacije (R) za provedbu, validaciju, ispitivanje i sve skupove podataka blizu 1. Srednja apsolutna pogreška (MAPE) i srednja

\footnotetext{
Authors are researchers at Karadeniz Technical University, Faculty of Forestry, Forest Industrial Engineering, Trabzon, Turkey.

Autori su istraživači Tehničkog sveučilišta Karadeniz, Šumarski fakultet, Inženjerstvo u šumarstvu, Trabzon, Turska.
} 
kvadratna pogreška (MSE) za sve su skupove podataka iznosile 2,94\% i 0,57. Kao rezultat ovog istraživanja može se preporučiti uporaba predloženog ANN modela za predviđanje upojnosti vode $i$ debljinskog bubrenja ploča umjesto složenih i dugotrajnih studija poput empirijskih formula.

Ključne riječi: umjetna neuronska mreža, upojnost vode, debljinsko bubrenje, ploča vlaknatica srednje gustoće, parafin

\section{INTRODUCTION}

1. UVOD

Fiberboard is a wood-based panel that consists of wood lignocellulosic fibers, produced using synthetic resins or other bonding systems/materials under different temperature and pressure conditions. It is commonly used in buildings and constructions as panel, insulating and covering materials. Fiberboard is frequently preferred for many furniture applications instead of particleboard, plywood and solid wood (Ye et al., 2007). Mechanical and physical properties of medium density fiberboard (MDF) change mainly depending on raw material properties (wood species, resin and additives) and production parameters (Ayrilmis, 2008).

It is known that fiberboard is a hygroscopic material like wood and other wood-based panels (Ayrilmis, 2007). When wood-based panels are exposed to moisture, some changes in dimensions and in their structure occur (Suzuki and Miyamoto, 1998). Therefore, this situation could be important for end use of the materials.

Some additives, which are known as water repellents, such as paraffin-wax, are used to improve the dimensional stability of fiberboards (Nazerian et al., 2014). In a previous study, the effects of some experimental parameters, including paraffin rates at 0,1 and $2 \%$, press temperature at $170-180{ }^{\circ} \mathrm{C}$, and press time for 4 and 5 minutes, on the mechanical and physical characteristics of MDF samples were investigated. It has been reported that, while the paraffin addition had no significant effect on the mechanical properties of MDF, the rate of water absorption decreased as the paraffin ratio increased. The researchers also concluded that the increasing press temperature showed the same effect for WA and TS values with increasing paraffin rate (Akrami et al., 2011). It was reported in another study (Winandy and Krzysik, 2007) that press temperature affected the dimensional properties of panels.

Recently, besides the classical methods and researches for determining the technological properties of materials, the use of artificial intelligence techniques has increased. Artificial neural network (ANN) is one of these artificial intelligence techniques. ANN is a logical software developed by imitating the working mechanism of the human brain, to perform basic functions such as brain learning the new information, recalling the learned information (Silva et al., 2017). ANN also provides estimates of intermediate values that cannot be performed in experiments and is frequently used in scientific work areas such as engineering (Khorasani and Yazdi, 2017; Gurgen et al., 2018), health sciences (Beauchet et al., 2018), etc. Recently, ANN has received considerable attention in the field of wood products industry. Akyüz et al. (2017) modeled formaldehyde emission based on process parameters in particleboard manufacturing process with ANN. Tiryaki et al. (2014) proposed an ANN model to predict surface roughness of wood in machining process. Fu et al. (2017) predicted elastic strain of white birch disks during drying using ANN. In addition, ANN was used to detect the structural damage in medium density fiberboard (Long and Rice, 2008), to predict bending strength and modulus of elasticity of structural plywood board (Fernández et al., 2012), to model the moisture absorption and thickness swelling of oriented strand board (Özşahin, 2012).

It is known that the values of water absorption and thickness swelling of materials show different trends depending on many different production parameters. Generally, WA and TS values of wood-based materials tend to increase unless some water repellant chemicals and treatments are used. In addition, it is possible to estimate the $W A$ and $T S$ values of panel samples at specific immersion times using an ANN model. There is limited study about modeling the effect of paraffin addition and hot press temperature on $W A$ and $T S$ of MDF in the literature. The objective of the present study is to develop an ANN model to predict the changes in the $W A$ and $T S$ values of MDF depending on some parameters such as different paraffin rates and press temperatures.

\section{MATERIALS AND METHODS 2. MATERIJALI I METODE}

\subsection{Medium density fiberboard production}

2.1. Proizvodnja ploča vlaknatica srednje gustoće

In this study, commercial beech-pine fibers were used as raw material to produce fiberboard. The fibers were dried in a laboratory oven until they reached $2 \%$ moisture content. Urea-formaldehyde (UF) was taken as adhesive at $13 \%$ ratio. Paraffin emulsion (solid content $37 \%$ ) were added to UF at the ratio of $0.5,1,1.5 \%$ by weight, and $1 \%$ ammonium chloride was used as hard-

Table 1 Panel types and experimental parameters Tablica 1. Vrste ploča i parametri istraživanja

\begin{tabular}{|c|c|c|}
\hline $\begin{array}{c}\text { Panel code } \\
\text { Oznaka ploče }\end{array}$ & $\begin{array}{c}\text { Press } \\
\text { temperature, } \\
\text { Temperatura }^{\circ} \mathbf{C} \\
\text { prešanja, }^{\circ} \mathrm{C}\end{array}$ & $\begin{array}{c}\text { Paraffin } \\
\text { addition rate, \% } \\
\text { Udio parafina, \% }\end{array}$ \\
\hline A0 & 170 & 0 \\
\hline A1 & 170 & 0.5 \\
\hline A2 & 170 & 1.0 \\
\hline A3 & 170 & 1.5 \\
\hline B0 & 190 & 0 \\
\hline B1 & 190 & 0.5 \\
\hline B2 & 190 & 1.0 \\
\hline B3 & 190 & 1.5 \\
\hline
\end{tabular}


ener. Later, adhesive was sprayed onto fibers and mats were manually formed. These mats were pressed at 170 , $190{ }^{\circ} \mathrm{C}$ for $7 \mathrm{~min}$ in a hot press. The panel density was set to $750 \mathrm{~kg} / \mathrm{m}^{3}$. Panels were produced with thickness of $10 \mathrm{~mm}$. Before the experiments, the produced panels were conditioned in an acclimatized room at $20^{\circ} \mathrm{C}$ and $65 \%$ relative humidity. The panel types and experimental parameters are presented in Table 1.

\subsection{Water absorption and thickness swelling \\ 2.2. Upojnost vode i debljinsko bubrenje}

The water absorption (WA) and thickness swelling (TS) of MDF samples within $24 \mathrm{~h}$ immersion in water were determined according to EN 317 (1993). The measurements of samples were carried out at 1,2 , $3,4,5,6,7,8,10,12,14,16,18,20,22$ and 24 hours.

Ten samples, $50 \mathrm{~mm} \times 50 \mathrm{~mm}$, were cut from panels and used for $W A$ and TS measurements. At the beginning of tests, weight and thickness of all samples were measured. Then, MDF samples were immersed in water at $20{ }^{\circ} \mathrm{C}$. At the end of each immersion time, the final thickness and weights of the samples were determined. The water absorption and thickness swelling of the MDF samples were calculated according to Eq. 1 and 2.

$$
W A=\left(W_{2}-W_{1}\right) / W_{1} \cdot 100
$$

$W A$ - water absorption (\%)

$W_{1}$ - weight before immersion $(\mathrm{g})$

$W_{2}$ - weight after immersion $(\mathrm{g})$

$$
T S=\left(\mathrm{T}_{2}-\mathrm{T}_{1}\right) / \mathrm{T}_{1} \cdot 100
$$

$T S$ - thickness swelling (\%)

$T_{1}$ - thickness before immersion ( $\mathrm{mm}$ )

$T_{2}$ - thickness after immersion ( $\mathrm{mm}$ )

All the experimental studies were carried out in the laboratory of the forest industrial engineering, Karadeniz Technical University. The precision scale (Radwag, AS 220.R2) was used to measure the weight of panel samples with high resolution of $0.0001 \mathrm{~g}$. Electronic digital caliper (Mitutuyo, 913-102) was used to measure the thickness of the same samples with resolution of $0.01 \mathrm{~mm}$.

\subsection{Artificial neural network (ANN)}

2.3. Umjetna neuronska mreža

ANN is one of the branches of artificial intelligence that can be applied in different disciplines. ANN consists of artificial neurons tied together with various weights and is usually organized in layers. It has a structure in which complex relationships can be learned between dependent and independent variables introduced to the network. There is no need for learning about the neural network system. ANN is only trained with the data. Therefore, it looks like a "black box" (Haykin, 1994; Sivamani et al., 2018). The fundamental structure of an artificial neural network is illustrated in Figure 1.

As shown in Figure 1, it consists of five main components: inputs, weights, summation function, activation function, and output.

The inputs provide the information to the neuron and they are independent variables of the problem. Weights are the coefficients that determine the influ-

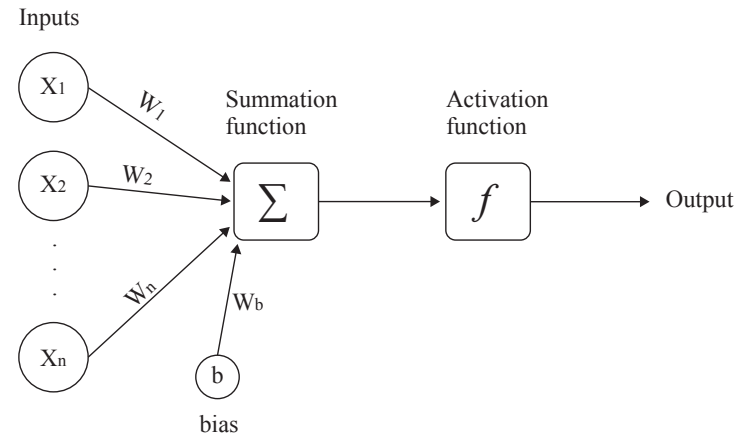

Figure 1 The fundamental structure of an artificial neural network

Slika 1. Temeljna struktura umjetne neuronske mreže

ence of inputs on the network. The summation function calculates the net input value for a neuron. Generally, it can be expressed as in Eq. 3 .

$$
N e t=\sum_{i=1}^{n} X_{i} \cdot W_{i}
$$

where, $X$ is input, $W$ is weight and $n$ is the number of samples.

The activation function processes the net input value and then produces the output. Linear function, sigmoid function and hyperbolic tangent function are commonly used as activation function.

The outputs are determined by the activation function and they are dependent variables of the problem. The weight values are initially chosen randomly to start the network training. These values are updated according to the learning rule in each iteration to obtain the desired output. Weights are completely random and have no meaning before training, but they become meaningful information after training. When ANN's performance reaches a satisfactory level, the training ends at this epoch and the network uses these weights to make decisions (Erdemir and Ayata, 2017). In general, the flow chart in Figure 2 can be followed when modeling any problem with ANN.

\section{MODELING OF PRESENT STUDY WITH ANN}

\section{MODELIRANJE SADAŠNJE STUDIJE ANN-om}

\subsection{Selection of input and output parameters}

3.1. Odabir ulaznih i izlaznih parametara

In order to model the problem correctly, it must be fully understood, and the variables must be selected correctly. It is easy to define the input and output parameters originating from the nature of some problems. However, preliminary research in the literature is needed to determine the input and output of some problems. In this work, paraffin content, press temperature and immersion time in water were used as the input variables, while WA and TS were used as the output variables. Figure 3 illustrates the architecture of ANN model.

\subsection{Choice of network structure}

3.2. Izbor mrežne strukture

There are many alternatives for the activation function, as described in the above section. The log- 


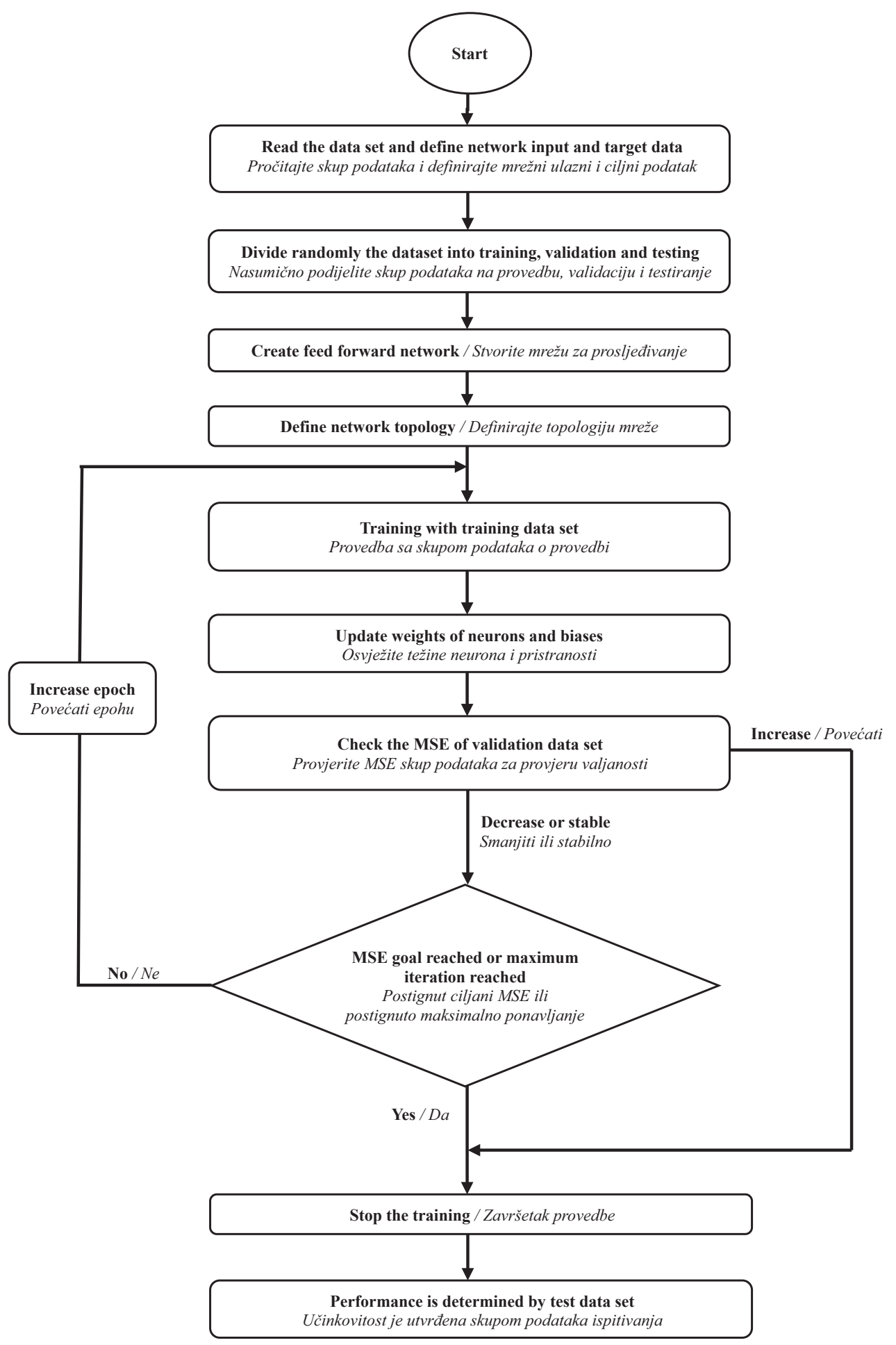

Figure 2 Flow chart of ANN modeling stages

Slika 2. Dijagram toka modeliranja uz pomoć ANN-a

sigmoid (logsig) function was chosen in the hidden layer, while the purelin function was applied in output layer as the activation functions. These functions are given in Eq. 3 and 4.

$$
\begin{gathered}
\log \operatorname{sig}(x)=\frac{1}{1+\mathrm{e}^{-x}} \\
\operatorname{purelin}(x)=x
\end{gathered}
$$

Performance function of the model was set to mean squared error (MSE) since it has advantageous features such as convexity, symmetry and differentiability. MSE was determined using Equation 5.

$$
M S E=\frac{1}{n} \sum_{i=1}^{n}\left(e_{i}-p_{i}\right)^{2}
$$

where is the experimental result, $p$ is the prediction result, and $n$ is the number of samples.

\subsection{Choice of learning rule \\ 3.3. Izbor pravila učenja}

Choosing an appropriate learning rule for optimizing network weights is crucial to the success of the network. The error between the actual value and predicted value of the network is minimized by a gradient descent approach, often known as back propagation 


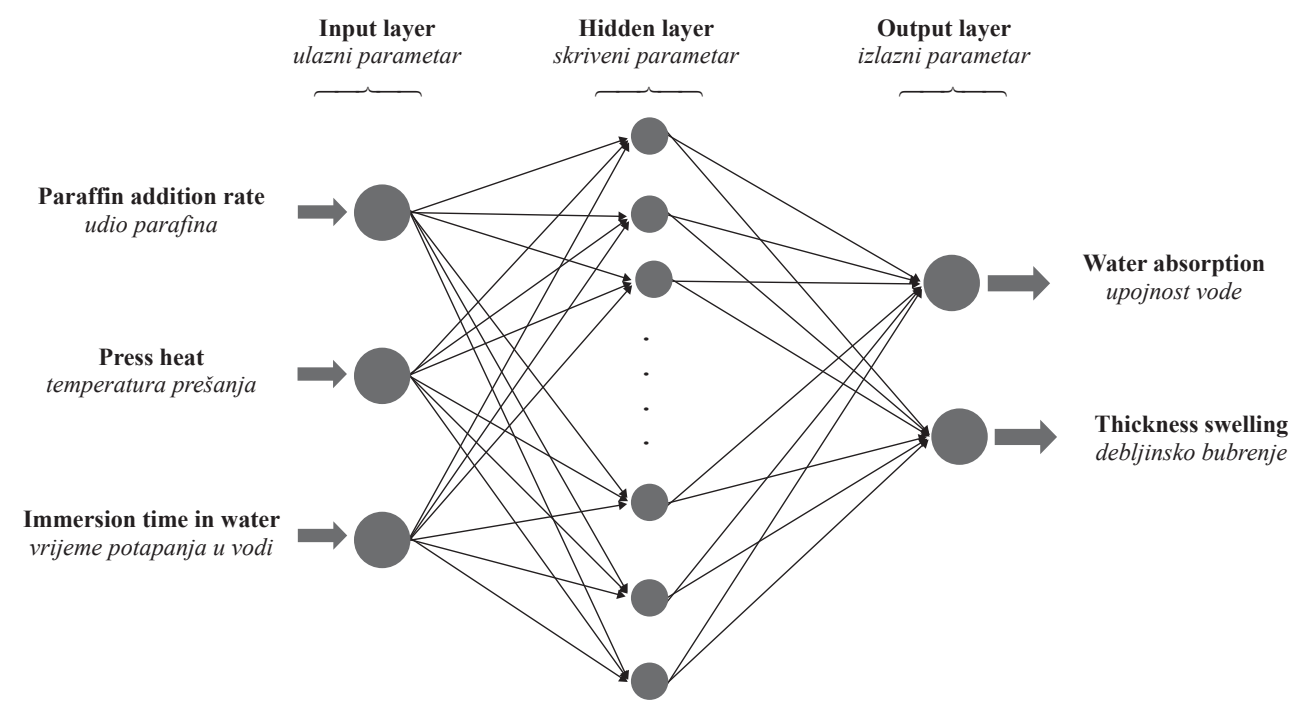

Figure 3 The architecture of ANN model

Slika 3. Arhitektura ANN modela

learning. The use of back propagation neural network in combination with various variants provides many benefits such as fast convergence.

In this study, both Levenberg-Marquardt (LM) and Scaled Conjugate Gradient (SCG) optimization algorithm were used. The performance of these two algorithms was compared and the most appropriate performance was chosen.

\subsection{Arrangement of data set \\ 3.4. Uređenje skupa podataka}

Three input and two output parameters were used to model this work. A total of 128 values were obtained after the experimental study. In ANN modeling, $70 \%$ (90 values) of all experimental data obtained for model training, $15 \%$ (19 values) for validation and $15 \%$ (19 values) for testing of network performance were utilized.

\subsection{Stopping criteria for ANN training}

3.5. Zaustavljanje kriterija za ANN provedbu

Three stopping criteria were determined for the current study. If the MSE value of validation data set continues to increase for a given epoch, the network training process is terminated. Maximum validation failure, which is the first stopping criteria, was set to 100 .
So, the MSE value was checked for 100 epochs and if the MSE did not decrease, then the training was stopped. The other stopping criterion was the target MSE value of the training data set. The performance target of the model that stopped the training stage was considered to be $10^{-6}$. Finally, the maximum number of epochs was determined as the last stopping criterion. The maximum number of epochs was selected as 500 epochs.

\subsection{Statistical evaluation of ANN models}

3.6. Statistička evaluacija ANN modela

MSE and mean absolute percentage error (MAPE) values were used to assess prediction performance of the proposed ANN models. MSE and MAPE were determined using Eq. 5 and 6.

$$
M A P E=\frac{1}{n} \sum\left|\frac{e_{i}-p_{i}}{p_{i}}\right| \cdot 100
$$

where is the experimental result, is the prediction result, and is the number of samples.

In this study, 30 different ANN structures were obtained by using two different training algorithms and 15 different $(5-20)$ hidden neuron numbers. The applied models were compared with each other and the final optimum model was proposed. Table 2 summarizes the ANN model topology.

Table 2 Model topology

Tablica 2. Model topologije

\begin{tabular}{|l|c|}
\hline Parameters / Parametri & Value / Vrijednost \\
\hline Training algorithm / algoritam provedbe & $\begin{array}{c}\text { Levenberg-Marquardt (trainlm), Scaled } \\
\text { Conjugate Gradient (trainscg) }\end{array}$ \\
\hline Performance function / izvedbena funkcija & Mean square error (mse) \\
\hline Hidden layer activation function / funkcija aktiviranja skrivenog parametra & Logistic sigmoid (logsig) \\
\hline Output layer activation function / funkcija aktiviranja izlaznog parametra & Linear transfer function (purelin) \\
\hline Number of hidden layers / broj skrivenih parametara & 1 \\
\hline Input layer nodes / čvorovi ulaznog parametra & 3 \\
\hline Hidden layer nodes / čvorovi skrivenog parametra & $5: 20$ \\
\hline Output layer nodes / čvorovi izlaznog parametra & 2 \\
\hline Maximum validation error epochs / epohe najveće pogreške u validaciji & 100 \\
\hline
\end{tabular}




\section{RESULTS AND DISCUSSION}

\section{REZULTATI I DISKUSIJA}

\subsection{Experimental studies}

\subsection{Eksperimentalne studije}

In this study, MDFs were produced using two different press temperatures and four different rates of paraffin. WA and TS values of the produced panel samples were measured for 16 different times within 24 hours. The maximum and minimum values determined among these periods are given in Table 3. In all experiments, the WA and TS values were calculated in the samples measured after 1 hour and 24 hours, respectively, and the minimum and maximum values are shown in Table 3.

As seen in Table 3, the WA and TS values decreased as the paraffin additive rate increased. Some researchers have investigated the effect of the chemical composition of paraffin and the emulsifier type on the hydrophobic properties of MDF. They have reported that high paraffin content $(>0.25 \%)$ had a significant effect on the swelling behavior of MDF and that $0.1 \%$ to $1.0 \%$ (relative to dry fibers) of paraffin rate did not have a negative impact on the physical and mechanical properties of panels (Roffael et al., 2005). Likewise, the $W A$ and $T S$ values of the panels produced at $190^{\circ} \mathrm{C}$ were found to be lower than those of the same contents produced at $170{ }^{\circ} \mathrm{C}$. It has been reported in previous studies that the press temperature and duration affected the water soaking properties of MDF (Li et al., 2009; Kargarfard et al., 2009).

\subsection{Modeling with ANN}

4.2. Modeliranje ANN-om

In this study, the results of $W A$ and $T S$ of 8 different MDFs were modeled at certain intervals within 24 hours. For this purpose, measurements were carried out at 1, 2, 3, 4, 5, 6, 7, 8, 10, 12, 14, 16, 18, 20, 22 and 24 hours. To select the optimum model, 15 different
(5-20) hidden neuron numbers and two different training algorithms were applied: LM and SCG. In general, various error values were calculated to determine the accuracy of an ANN model. The smaller value of these errors means that the proposed model is more reliable. $M A P E$ and MSE were used as the performance criterion of the model in this study. The network with the lowest $M A P E$ and $M S E$ value from the applied models was obtained in the LM algorithm and at 16 hidden neurons. When the performance values of applied networks were examined, it was concluded that the LM algorithm predicts the $W A$ and $T S$ rates with minimum $M A P E$ and MSE, and lower than SCG algorithm. So, the optimal ANN architecture was found as model architecture, which has three neurons in input layer, sixteen neurons in hidden layer and two neurons in output layer (3-16-2). MAPE and MSE results of WA and TS of the optimal network among the applied networks are given in Table 4 and 5.

As shown in Table 4, MAPE values for $W A$ were found to be $1.15 \%, 6.44 \%$ and $6.63 \%$ for training, validation and testing data set, respectively. In addition, $M A P E$ was determined as $2.75 \%$ for all data set. $M A P E$ values for the training, validation, test and all data of the proposed ANN model were found to be 2.53 $\%, 4.2 \%, 4.88 \%$ and $3.13 \%$, respectively. When two outputs were evaluated together, MAPE values were found to be $1.84 \%$ for training, $5.33 \%$ for validation and $5.75 \%$ for test data. As a result, error value including all data was found to be $2.94 \%$. This result shows that the proposed model produces forecast results with high reliability.

It can be seen that $M S E$ values were calculated as $0.27,2.44,2.84$ and 0.97 for training, validation, test and all data, respectively, for $W A$ rates (Table 5). MSE values for $T S$ were determined as $0.14,0.20,0.26$ and 0.17 for training, validation, test and all data, respectively. When two outputs were evaluated together,

Table 3 The maximum and minimum values of measurements

Tablica 3. Najveće i najmanje vrijednosti mjerenja

\begin{tabular}{|c|c|c|c|c|c|}
\hline \multirow{2}{*}{$\begin{array}{c}\text { Press temperature, }{ }^{\circ} \mathbf{C} \\
\text { Temperatura prešanja, }\end{array}{ }^{\circ} \mathrm{C}$} & \multirow{2}{*}{$\begin{array}{c}\text { Panel code } \\
\text { Oznaka ploče }\end{array}$} & \multicolumn{2}{|c|}{$\begin{array}{c}\text { Water absorption, \% } \\
\text { Upojnost vode, \% }\end{array}$} & \multicolumn{2}{|c|}{$\begin{array}{c}\text { Thickness swelling, \% } \\
\text { Debljinsko bubrenje, \% }\end{array}$} \\
\cline { 3 - 6 } & & Max. & Min. & Max. & Min. \\
\hline \multirow{3}{*}{170} & $\mathrm{~A} 3$ & 54.94 & 9.11 & 21.67 & 3.98 \\
\cline { 2 - 6 } & $\mathrm{A} 2$ & 83.64 & 15.35 & 24.07 & 4.53 \\
\cline { 2 - 6 } & $\mathrm{A} 1$ & 85.32 & 15.65 & 28.20 & 4.59 \\
\cline { 2 - 6 } & $\mathrm{A} 0$ & 99.62 & 15.68 & 29.17 & 5.04 \\
\hline \multirow{3}{*}{190} & $\mathrm{~B} 3$ & 40.05 & 6.65 & 15.20 & 2.20 \\
\cline { 2 - 6 } & $\mathrm{B} 2$ & 49.73 & 7.18 & 16.31 & 2.65 \\
\cline { 2 - 6 } & $\mathrm{B} 1$ & 54.55 & 11.50 & 18.11 & 3.62 \\
\cline { 2 - 6 } & $\mathrm{B} 0$ & 59.54 & 12.01 & 19.34 & 3.88 \\
\hline
\end{tabular}

Table 4 MAPE results of $W A$ and $T S$ of optimum network

Tablica 4. MAPE rezultati $W A$ i $T S$ optimalne mreže

\begin{tabular}{|l|c|c|c|c|}
\hline & $\begin{array}{c}\text { Train data, \% } \\
\text { Podatci } z a \\
\text { provedbu, \% }\end{array}$ & $\begin{array}{c}\text { Validation data, \% } \\
\text { Podatci za } \\
\text { validaciju, \% }\end{array}$ & $\begin{array}{c}\text { Test data, \% } \\
\text { Podatci za } \\
\text { testiranje, \% }\end{array}$ & $\begin{array}{c}\text { All data, \% } \\
\text { Svi podatci, \% }\end{array}$ \\
\hline Water absorption / Upojnost vode & 1.15 & 6.44 & 6.63 & 2.75 \\
\hline Thickness swelling / Debljinsko bubrenje & 2.53 & 4.21 & 4.88 & 3.13 \\
\hline Mean value / Srednja vrijednost & 1.84 & 5.33 & 5.75 & 2.94 \\
\hline
\end{tabular}


.... Gürgen, Ustaömer, Yildiz: Application of Artificial Neural Network to Predict the Effect...

Table 5 MSE results of $W A$ and $T S$ of optimum network

Tablica 5. MSE rezultati $W A$ i $T S$ optimalne mreže

\begin{tabular}{|l|c|c|c|c|}
\hline & $\begin{array}{c}\text { Train data } \\
\text { Podatci za } \\
\text { provedbu }\end{array}$ & $\begin{array}{c}\text { Validation data } \\
\text { Podatci za } \\
\text { validaciju }\end{array}$ & $\begin{array}{c}\text { Test data } \\
\text { Podatci za } \\
\text { testiranje }\end{array}$ & $\begin{array}{c}\text { All data } \\
\text { Svi podatci }\end{array}$ \\
\hline Water absorption / Upojnost vode & 0.27 & 2.44 & 2.84 & 0.97 \\
\hline Thickness swelling / Debljinsko bubrenje & 0.14 & 0.20 & 0.26 & 0.17 \\
\hline Mean value / Srednja vrijednost & 0.21 & 1.32 & 1.55 & 0.57 \\
\hline
\end{tabular}

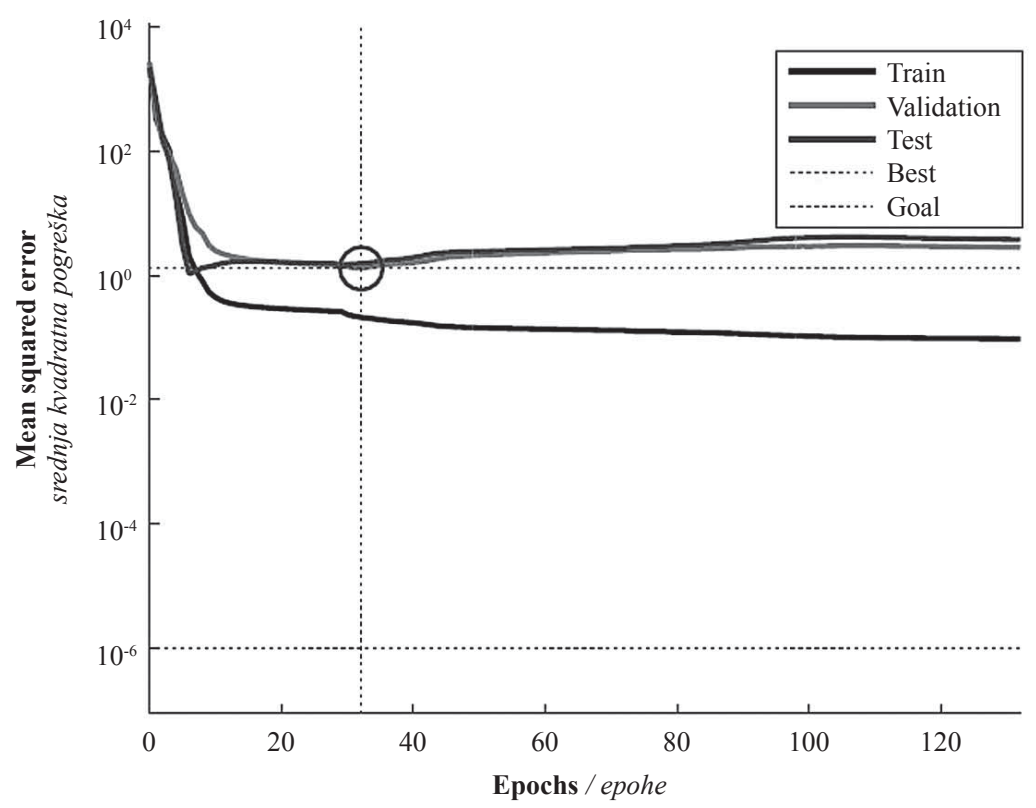

Figure 4 Performance graphic of the training stage Slika 4. Grafika provedbene faze
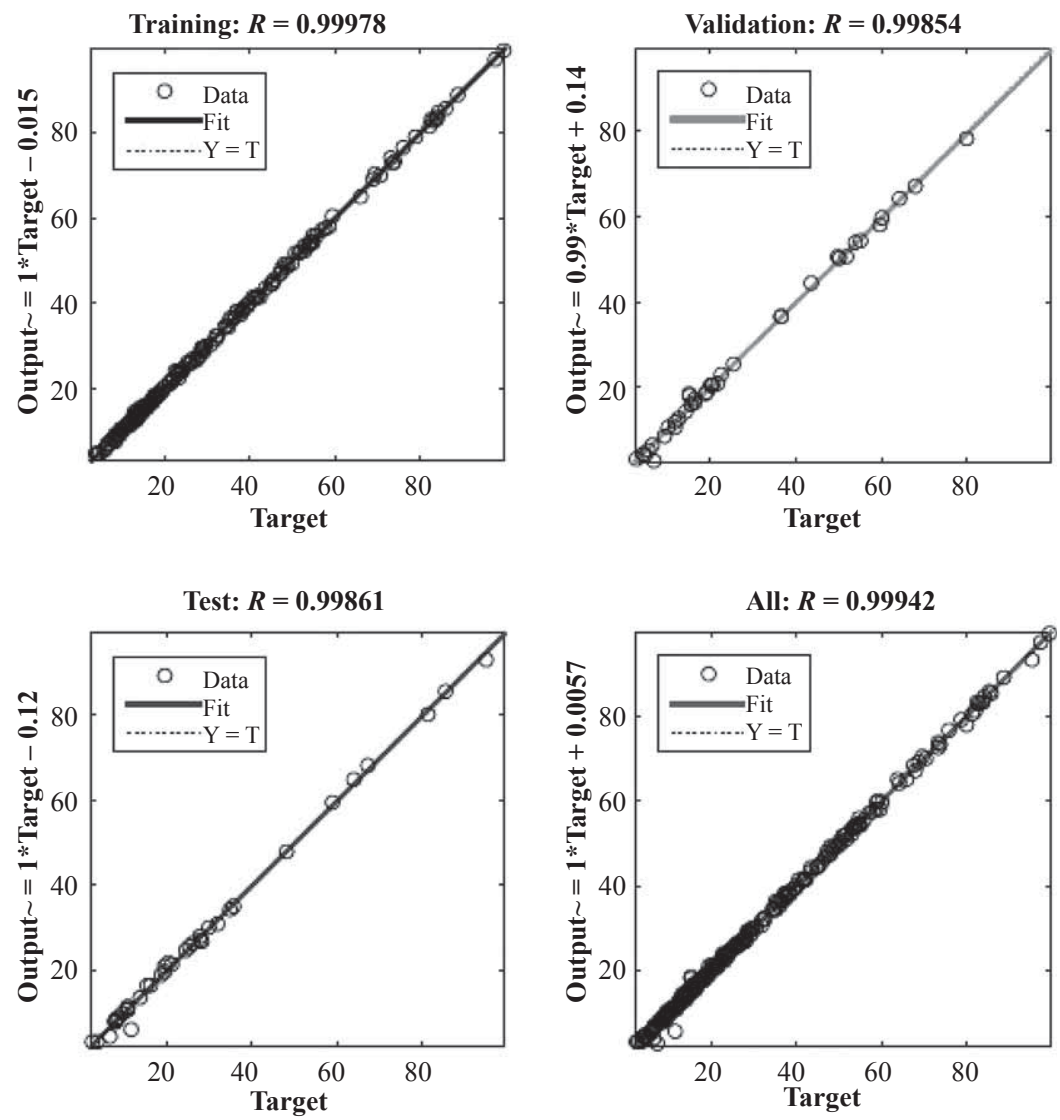

Figure 5 Regression graphics of the optimal network for training, validation, test and all data

Slika 5. Regresijske grafike optimalne mreže za provedbu, validaciju, testiranje i za sve podatke 
MSE values were found to be 0.21 for training, 1.32 for validation and 1.55 for test data. As a result, error value including all data was found to be 0.57 . Similar to $M A P E$ values, $M S E$ values were also seen to be very low, and this supports the statement that the model prediction reliability is quite high.

As shown in Figure 4, the MSE of the validation data tended to increase after the $32^{\text {nd }}$ epoch, and this trend continued throughout the 100 epoch, which is the validation of results. This means that the network has begun to memorize instead of learning. Therefore, network training was stopped on the $32^{\text {nd }}$ epoch, when optimal networking was achieved.

Figure 5 depicts the regression graphics of the network with the best performance recommended in this study. The correlation coefficients $(R)$ were calculated as $0.99978,0.99854,0.99861$ for training, validation and testing data sets, respectively. When all the data are considered together, $R$ is found to be 0.99942 . It means that the prediction results are in correlation with experimental results, hence $R$ value is close to one.

\section{CONCLUSIONS}

\section{ZAKLJUČAK}

This study consists of two stages: experimental study and development of an ANN model. A total of 128 data obtained from experimental study were used to set an ANN model. The number of different hidden neurons (5-20) and two different training algorithms (LM and SCG) were used to achieve the optimal network with the best performance. As a result, the optimal network was obtained in 16 hidden neurons and the LM algorithm. Results showed that the experimental and predicted values were well correlated with each other. The important finding of the present study can be summarized as follows:

While the values of $W A$ and $T S$ decreased with the increment of paraffin rate and press temperature, same values increased with an increase in water immersion time.

The maximum value of $W A$ was determined as $99.62 \%$, which was obtained from A0 panel at 24th hours. The minimum value of $W A$ was determined as $6.66 \%$, which was obtained from B3 panel at 1st hours.

The maximum value of $T S$ was calculated as $29.17 \%$, which was obtained from A0 panel at 24th hours. The minimum value of $T S$ was calculated as $2.20 \%$, which was obtained from B3 panel at 1st hours.

$M A P E$ values of proposed ANN model were in the range of 1.15-6.44\%. In addition, $M A P E$ including all data was found to be $2.94 \%$.

$M S E$ values of proposed ANN model were in the range of $0.15-2.85$. In addition, MSE including all data was found to be 0.58 .

The correlation coefficient values for the training, validation, test and all data of the proposed ANN model were found to be $0.99978,0.99854,0.99861$ and 0.99942 , respectively.

Applicability of ANN has been proved to predict water absorption and thickness swelling of MDFs.

\section{REFERENCES}

\section{LITERATURA}

1. Akrami, A.; Doosthoseini, K.; Faezipour, M.; Jahan Latabari, A., 2011: The effect of paraffin addition and pressing conditions on some properties of medium density fiberboard (MDF) with emphasis on surface roughness. Journal of Forest and Wood Products, 64: 343-353.

2. Akyüz, İ.; Özşahin, Ş.; Tiryaki, S.; Aydın, A., 2017: An application of artificial neural networks for modeling formaldehyde emission based on process parameters in particleboard manufacturing process. Clean Technol. Environ., 19 (5): 1449-1458.

https://doi.org/10.1007/s10098-017-1342-0.

3. Ayrilmis, N., 2007. Effect of panel density on dimensional stability of medium and high density fiberboards. Journal of Materials Science, 42 (20): 8551-8557. https://doi.org/10.1007/s10853-007-1782-8.

4. Ayrilmis, N., 2008. Effect of compression wood on dimensional stability of medium density fiberboard. Silva Fennica, 42 (2): 285-293.

5. Beauchet, O.; Noublanche, F.; Simon, R., 2018: Falls risk prediction for older inpatients in acute care medical wards: Is there an interest to combine an early nurse assessment and the artificial neural network analysis? The Journal of Nutrition Health and Aging, 22 (1): 131-137. https://doi.org/10.1007/s12603-017-0950-z.

6. Da Silva, I. N.; Hernane Spatti, D.; Andrade Flauzino, R.; Liboni, L. H. B.; dos Reis Alves, S. F., 2017: Artificial Neural Networks, Springer. https://doi.org/10.1007/978-3-319-43162-8.

7. Erdemir, D.; Ayata, T., 2017: Prediction of temperature decreasing on a green roof by using artificial neural network. Applied Thermal Engineering, 112: 1317-1325. https://doi.org/0.1016/j.applthermaleng.2016.10.145.

8. Fernández, F. G.; de Palacios, P.; Esteban, L. G., GarciaIruela, I.; Rodrigo, B. G.; Menasalvas, E., 2012: Prediction of MOR and MOE of structural plywood board using an artificial neural network and comparison with a multivariate regression model. Composites Part B: Engineering, 43 (8): 3528-3533. https://doi.org/10.1016/j.compositesb.2011.11.054.

9. Fu, Z.; Avramidis, S.; Zhao, J.; Cai, Y., 2017: Artificial neural network modeling for predicting elastic strain of white birch disks during drying. European Journal of Wood and Wood Products, 75 (6): 949-955. https://doi.org/949-955;10.1007/s00107-017-1183-x.

10. Gurgen, S.; Altin, I.; Ozkok, M., 2018: Prediction of main particulars of a chemical tanker at preliminary ship design using artificial neural network. Ships and Offshore Structures, 13 (5): 459-465.

https://doi.org/10.1080/17445302.2018.1425337.

11. Haykin, S., 1994: Neural Network: A Comprehensive Foundation. New York, Macmillan College.

12. Kargarfard, A.; Nourbakhsh, A.; Hajihassani, R., 2009: The effect of press temperature and press time on medium density fiberboard (MDF) properties produced from Eucalyptus intertexta fibers. Iranian Journal of Wood and Paper Science Research., 24 (1): 26-35.

13. Khorasani, A.; Yazdi, M. R. S., 2017: Development of a dynamic surface roughness monitoring system based on artificial neural networks (ANN) in milling operation. The International Journal of Advanced Manufacturing Technology, 93 (1-4): 141-151. https://doi.org/10.1007/s00170-015-7922-4.

14. Li, X.; Li, Y.; Zhong, Z.; Wang, D.; Ratto, J. A.; Sheng, K.; Sun, X. S., 2009: Mechanical and water soaking 
properties of medium density fiberboard with wood fiber and soybean protein adhesive. Bioresource Technology, 100 (14): 3556-3562. https://doi.org/10.1016/j.biortech.2009.02.048.

15. Long, W.; Rice, R. W., 2008: Detection of structural damage in medium density fiberboard panels using neural network method. Journal of Composite Materials, 42 (11): 1133-1145. https://doi.org/10.1177/0021998308090455.

16. Nazerian, M.; Dalirzadeh, A.; Farrokhpayam, S. R., 2014: Use of almond shell powder in modification of the physical and mechanical properties of medium density fiberboard. BioResources, 10 (1): 169-181.

17. Özşahin, Ş., 2012: The use of an artificial neural network for modeling the moisture absorption and thickness swelling of oriented strand board. BioResources. 7 (1): 1053-1067.

18. Roffael, E., Schneider, T., Dix, B., Buchholz, T., 2005: On paraffin sizing of medium density fiberboards (MDF). Part 1: Influence of the chemical composition of paraffin and type of emulsifier on the hydrophobic properties of MDF. Holz als Roh- und Werkstoff, 63 (3): 192-203. https://doi.org/10.1007/s00107-004-0556-0.

19. Sivamani, S.; Selvakumar, S.; Rajendran, K.; Muthusamy, S., 2018: Artificial neural network - genetic algorithm-based optimization of biodiesel production from Simarouba glauca. Biofuels, 1-9. https://doi.org/10.1080/17597269.2018.1432267.

20. Suzuki, S.; Miyamoto, K; 1998: Effect of manufacturing parameters on the linear expansion and density profile of particleboard. J. Wood Sci., 44 (6): 444-450.
21. Tiryaki, S.; Malkoçoğlu, A.; Özşahin, Ş., 2014: Using artificial neural networks for modeling surface roughness of wood in machining process. Construction and Building Materials, 66: 329-335.

https://doi.org/10.1016/j.conbuildmat.2014.05.098.

22. Winandy, J. E.; Krzysik, A. M., 2007: Thermal degradation of wood fibers during hot-pressing of MDF composites: Part I. Relative effects and benefits of thermal exposure. Wood and Fiber Science, 39 (3): 450-461.

23. Ye, X. P.; Julson, J.; Kuo, M.; Womac, A.; Myres, D., 2007: Properties of medium density fiberboards made from renewable biomass. Bioresource Technology, 98 (5): 1077-1084. https://doi.org/10.1016/j.biortech.2006.04.022.

24. ***EN-317: 1993 European Committee for Standardization, Particleboards and fibreboards, determination of swelling in thickness after immersion in water, Brussels.

\section{Corresponding address:}

\section{AYSENUR GÜRGEN, Ph.D.}

Karadeniz Technical University

Faculty of Forestry

Forest Industrial Engineering

Trabzon, TURKEY

ORCID: 0000-0002-2263-7323

e-mail: aysenur.yilmaz@ktu.edu.tr 